\title{
Article
}

\section{Vagrant Presences: Lost Children, the Black Atlantic, and Northern Britain}

\author{
Rice, Alan
}

Available at https://clok.uclan.ac.uk/18084/

Rice, Alan orcid iconORCID: 0000-0002-2215-4727 (2017) Vagrant Presences: Lost Children, the Black Atlantic, and Northern Britain. ZAA - Zeitschrift fuer Anglistik und Amerikanistik A Quarterly of Language, Literature and Culture . ISSN 2196-4726

It is advisable to refer to the publisher's version if you intend to cite from the work. http://dx.doi.org/10.1515/zaa-2017-0019

For more information about UCLan's research in this area go to http://www.uclan.ac.uk/researchgroups/ and search for <name of research Group $>$.

For information about Research generally at UCLan please go to http://www.uclan.ac.uk/research/

All outputs in CLoK are protected by Intellectual Property Rights law, including Copyright law. Copyright, IPR and Moral Rights for the works on this site are retained by the individual authors and/or other copyright owners. Terms and conditions for use of this material are defined in the policies page.

\section{CLoK}

Central Lancashire online Knowledge www.clok.uclan.ac.uk

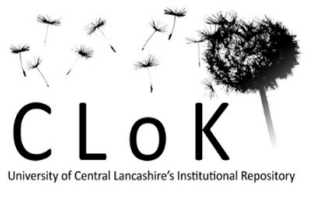




\section{Alan Rice $_{1}$}

Vagrant Presences: Lost Children, the Black Atlantic, and Northern Britain.

Abstract: This article discusses a range of African Atlantic figures whose vagrant and vagabond lifestyles help to broaden Paul Gilroy's conception of the Black Atlantic. Geographically, the author moves away from metropolitan concerns to discuss the rural and the provincial as key areas to discover hidden truths about African Atlantic peoples. The article investigates North British historical concerns from slavery and its aftermath in Scotland to the Cotton Famine in Lancashire. ItHe takes a close look at the radical Scots-descended Robert Wedderburn, the North-of-England-based, circus performer Pablo Fanque and the fugitive slave and wanderer James Johnson. ItHe also discusses contemporary artistic responses to black presence in North Britain by Ingrid Pollard and Jade Montserrat to show how these presences are being remembered and reimagined. ItHe uses the theoretical model developed by Michael Rothberg of "multi-dimensional memory" to investigate the way these historical characters and events are key to the fullest understanding of the bBlack Atlantic in Britain and beyond.

\section{The Black Atlantic On the RoadIntroduction}

There were about 17 mills around Rochdale, so it was doing the road work or starving. It was just one way of putting bread on the table for years. The road is a living memory of what happened and that's why we want to preserve it. (Roy Thorniley qtd. in "BBC’s 'Black History of Britain'” 2016)

Most articles about the Black Atlantic originate in the ocean with either middle passage woes or liberating sojourns; oceanic and free-floating or below-decks and chained, these narratives have held us in their grip and determined our perspectives ever since internationalist Black Cultural Studies and its routed realities received a timely boost from Paul Gilroy's epochal work The Black Atlantic: Modernity and Double Consciousness in 1993. I want to start elsewhere in order to propose a more localised and vagabondish perspective, one often forged within the memory of țTransatlantic passages but proposing new journeys, often tied to specific

1 Corresponding author: Prof. Alan Rice, Professor in English and American Studies, Co-Director-Institute for Black Atlantic Research (IBAR), School of Humanities and the Social Sciences, University of Central Lancashire, Livesey House 209, Preston, PR1 2HE, United Kingdom, e-mail: arice@uclan.ac.uk 
land-based locales, the connection of which to African presence is often obscured and forgotten. I want to range across geographies and chronologies to propose a model for the Black Atlantic that is not hidebound by petty particularism and essentialism but will hopefully bring out synergies that link a memorial road in Rochdale to a travelling, performing vagrant who finally finds a home in Oldham and to an earlier proto-Anarchist vagrant visiting his aristocratic father outside Edinburgh: from a circus performer buried in Leeds to a novelist from that city blackening Bronteë country and a contemporary artist burying herself with Yorkshire clay near Anne Bronteê̈'s burial place in Scarborough. Such narratives are discussed in the context of Britain as a nation imbued with "post-imperial melancholia” where, according to Gilroy, "the error of imagining that post-colonial people are only unwanted alien intruders without any substantive historical, political or cultural connections to the collective life of their fellow subjects" (Gilroy 2004, 98) is ubiquitous.

The epigraph above illustrates the connectivity of African Atlantic histories with the imperial, transnational and local; it emergeomes from an event in August 2016, organised by the Rooley Moor Neighbourhood Forum in Rochdale, near Manchester, to commemorate the 1863 Cotton Famine where ethnically British and Irish cotton workers were made unemployed in their tens of thousands because of the North's blockade of Southern cotton. The road-work was organised by local parish councils to provide employment for some of the starving workers and was a literal life-line at a time when some Northern white working-class people died of starvation. The ultimate cause was the fight against slavery raging in the United States, its consequences played out in mill-towns across the North West of Britain. The event saw the unveiling of a plaque about the historical events seen as important to keep the memory alive, not only of the plight of the workers, but also of the sacrifices made by some workers who organised meetings of solidarity with enslaved Africans which led to food parcels being sent to towns like Rochdale by Abraham Lincoln's government. One of the flour barrels sent by Lincoln is preserved in Rochdale Museum with its original message of solidarity. The barrel proclaims:

I am one of the thousands that were filled with flour and sent by the Free States of America in the ship George Griswold to the starving people of Lancashire whose miseries were caused by the aggressive and Civil War of the slave owners in 1862-34. (“Flour Barrel,” n.d., n. pag.)

The privations of the workers and this solidarity across the ocean between the British white working class and enslaved Africans in America, areis memorialised by the road and its new 
plaque. A road and its wayfarers becomes here a marker of the history of the fight against Transatlantic Slavery rather than a ship and its passengers (free and/or enslaved). Workingclass European whites' and enslaved Africans' shared experiences and the memory of them exemplify a multidirectionality that Michael Rothberg's seminal work shows as crucial for understanding the interconnectedness of histories of oppression that promote an antiessentialist ideology. He describes how:

Memories are not owned by groups_-nor are groups owned by memories. Rather the borders of memory and identity are jagged: what at first looks like my own property often turns out to be a borrowing or adaption from a history that might seem foreign or distant. Memory’s anachronistic quality-its bringing together of now and then, here and there-is actually the source of its powerful creativity, its ability to build new worlds out of the materials of old ones. (Rothberg 2009, 5)

Our understanding of Black British history and of Black Atlantic history can be crucially nuanced by understanding its intersections with local histories and memories, such as here, that of working-class, Northern adaptions to and folk memories of the debilitating Lancashire Cotton Famine. The memorialising of this road alerts us to other obscurantist narratives that help us to a more nuanced understanding of the Black Atlantic that is not hidebound to familiar tropes of slave narratives and heroic struggles for freedom, often played out in large plantations or in significant metropoles where black populations keep these memories of struggle alive.

Of course these are vital but sometimes other compelling narratives can be found in the banal and the everyday, in the strange and curious, in the carnivalesque and performative, in the vagabond and proletarian. The "borders of memory and identity" are indeed "jagged" and allow us to intersect black and white working-class memory in the North (and elsewhere), inviting new voices to speak seemingly "foreign or distant" truths right in the heart of the British polity. For instance, the discussion of the importance of the road to tell us the story of the American Civil War and its deadly effects on Britain links to a narrative of the vagrant and proletarian, James Johnson's The Life of the Late James Johnson, Coloured Evangelist: An Escaped Slave from the Southern States of America, 40 Years Resident in Oldham (1914). This pamphlet details the wandering of Johnson on his arrival in Britain in December 1862 at the height of extreme unemployment and its attendant misery:

I was worse now than ever-cotton stockings and a pair of slippers in bleak December, friendless and homeless, roaming the streets of Liverpool. I walked over to Southport, 
and finding nothing to do, walked by Ormskirk to St. Helens, on to Warrington, thence to Manchester; again on to Wigan, Huddersfield, Leeds, York, Beverley and Hull, where I took to singing, dancing and rattlebones, which I found was easier than begging. (Johnson 1914, 13)

James Johnson's torturous wanderings through northern England in December 1862 are unremarkable for a working-class man seeking employment at the height of the Lancashire Cotton Famine. Yet his sojourn was different and, despite the hardship, strangely liberating, for he had played his part in the Civil War that had caused the embargo of cotton which had created these awful conditions. An African American slave, escaping to Union lines earlier in 1862, he had withdrawn his enforced labour from the Confederate cause and had then travelled to Britain to ensure his freedom away from a country stained by the 'Peculiar Institution.'

Finally settling in Oldham a few miles away from the road in Rochdale, his brief autobiography was published posthumously in 1914 by his Lancashire-born daughter and lay almost completely unread until its rediscovery during the bicentenary of the abolition of the slave-trade commemorations in 2007. Such working-class black voices are rare in Victorian Britain, especially beyond London, but their uncovering is vital to tell the fully nuanced story of black people in Britain and more widely to understand the workings of Black Atlantic culture beyond the seaboard. His wanderings took him on round trips of over 300 miles before he settled in Oldham. His description of himself without proper shoes or woollen warmers in a harsh winter environment shows his desperate circumstances in what he was hoping was his promised land of freedom away from the slave-infested American polity. His poverty is a direct contrast to other liberating sojourners such as Frederick Douglass's or William Wells Brown's, the darlings of abolitionist, liberal Britons whose visits in the 1840s and 1850s made them the inhabitants of drawing rooms and parlours in their comparatively lavish speaking tours. Not willing to continue a beggar, Johnson used his cultural resources to perform to gain money for his vital needs. His description of "singing, dancing and rattlebones" (as cited above) underlines the way he brought with him cultural forms learnt on the plantations, distributing, as he travelled, African Atlantic cultural forms which would have been new in many of the wayside haunts he inhabited. His black wandering presence in small towns like Beverley, St. Helens and Ormskirk, let alone smaller unnamed places inbetween brought cosmopolitan blackness where it was rare and sometimes unheard of. 
The equestrian circus performer and proprietor Pablo Fanque (1796-1871) illustrates the landlubber, peripatetic nature of some black Victorian lives who brought cosmopolitan blackness to the masses. He was born William Darby in Norwich, the son of an African-born butler, but his interest in the circus took him far from his East Anglian roots. He was a master at equestrian tricks, rope walking, mighty leaps and rope vaulting. His circus became famous from the 1830s through to the end of the 1860s before his death in Stockport in 1871. His colourful career took him all over the country but his favourite environs were in the small and major mill towns of Lancashire such as Halsingden, Rawtenstall, and Bolton where "by his own industry and talent he got together as fine a stud of horses and ponies as any in England" (Turner 2003, 22). He was "the loftiest jumper in England [...] leaping over a post chaise placed lengthwise with a pair of horses in the shafts and through a military drum at the same time" (Turner 2003, 21). His circus played numerous venues having prestigious shows at the Manchester Free Trade Hall (1851-1852) and the Manchester Philharmonic (1855) but also visiting locations as diverse as Cork and South Shields, Belfast and Paisley, Huddersfield and Dublin. In the 1860s he annually erected his circus for the fair in Manchester: "Pablo's circus used to stand at the Knott Mill Fair Ground at the side near the station, each Easter. Pablo's occupied half that side of the ground, the other half being taken up with Wombwell's Beast Show" (Turner 2003, 312). Other circuses and menageries toured alongside his, including Hilton's Menagerie whose West-Indian-born lion tamer Makomo (a.k.a. Arthur Williams) was reported in the Manchester procession “dressed as a wild man in skin and feathers.” Obviously, more in control of his performance on his return "he had discarded his skin and feathers and appeared in a very good black suit” (Turner 2003, 21).

The dangers of being asked to play the minstrel were obvious in the mid--nineteenth century when imperial racialist ideas infected popular cultural forms like the musical theatre and circus culture. It is a testament to Fanque and Williams that they resisted or manipulated racial stereotypes in their favour to create enormously successful careers. Fanque, in particular, undermined the stereotypes that would have black artistes as subservient, bit part players in the circus world, rising through the ranks to run his own company. In describing how he was apprenticed to Fanque in 1865 at the age of fourteen, the later famous circus clown Whimmy Walker wrote of his employer:

Fanque, a coloured gentleman, a thorough master of his profession taught me to ride, to tumble, to perform on the trapeze [...] I was with Pablo 'till he died. I was entrusted to buy hay for the horses; I acted as veterinary surgeon, I could tell when a horse was lame, 
when he was ill I knew what was the matter with him; and all this useful knowledge I must say I owe to Pablo Fanque. [...] He was certainly one of the best masters. (qtd. in Turner 2003, 32)

Walker describes Fanque as an ideal mentor and describes him as a "master of his profession." More tellingly, he describes him as “one of the best masters.” At a time when slavery was only just being abolished in the United States and when the operations of a global empire meant that black British people were often thought of as inferior, Fanque's role as master to white apprentices in the liminal world of the circus and the acknowledgment of his skill in training them by his peers shows that status did not always follow racial hierarchies so readily away from the centres of national and imperial power.

Fanque's fame is assured by the backstory to the lyrics of the John Lennon written, Beatles song “For the Benefit of Mr Kite” from Sgt. Pepper's Lonely Hearts Club Band which was based on an antique circus poster (possibly from 1843 from Rochdale when there was a benefit element for Mr Kite in Fanque’s show) which highlighted Fanque's famed circus. Lennon is photographed pointing at the poster, illustrating a carnivalesque sepia-tinged Ye Olde England (“Lennon’s Poster” 2012). For him the name Pablo Fanque is a mere exoticism, but from our perspective he complicates such Anglo-centric and nostalgic readings of British and Northern history, illustrating a black presence right at the heart of vernacular culture in the most disparate regions of the nation. The story of the Beatles is usually told with its links to black culture through imported blues-tinged black American music influencing the style and content of British pop music. Discovering black performativity as an historical and usually forgotten underground form contributing formative ideas to a seminal Beatles album illustrates a chronological and geographical multidimensionality to the tangled histories of popular culture. Michael Rothberg describes the importance of attending to memory’s multiplicities describing how moving from essentialism, particularism and competitive victimhood between classes, races and ethnicities can lead to richer and more politically astute interpretations of our complex historical narratives. He describes how:

$[$ ii]t is precisely that convoluted, sometimes historically unjustified, back and forth movement of seemingly distant collective memories in and out of public consciousness that I qualify as memory's multidirectionality. [...] Thinking of memory as multidirectional instead of competitive does not entail dispensing with a notion of the urgency of memory, with its life-and-death stakes. Rather these examples alert us to the 
need for a form of comparative thinking that, like memory itself, is not afraid to traverse sacrosanct borders of ethnicity or era. (Rothberg 2009, 17)

Pablo Fanque's achievements, his residual memory and the happenstance of its emergence into popular culture through the sixties counter-culture warns us against the erecting of boundaries that seek to limit the meaning of the past ethnocentrically or to keep it past. His wandering, liminal and vagrant history (for despite his status as a famous circus proprietor, he lived on the edge of economic security and died destitute) still has repercussions today. This is attested to by a new black historical walk inaugurated in Leeds in 2009, where he is buried, which foregrounds his presence as a key one in telling the black history of the city. His funeral in 1871 included a band playing the "Dead March" while his favourite horse, Wallett, was brought over from Stockport by Whimmy Walker to lead the procession during which "a densely packed crowd lined the funeral route" (Turner 2003, 34) to Woodhouse cemetery where his body was interred with the headstone still visible today. Such a momentous event was forgotten in the collective memory of the city right up until the reinstatement of Fanque into the history of the city in the wake of the Bicentenary of the Abolition of the Slave Trade in 2007. This showed the kind of "comparative thinking” Rothberg urges on us to discover synergies between histories and memories. These enable us to understand the ways so-called minority histories are in fact often fully imbricated and vital to majoritarian histories altering their all too often monolingual historiographies. Fanque’s history, its narrative and its retelling in different eras is a leitmotif for the importance of multidimensional memory, particularly for the furtherance of the awareness of heretofore forgotten or marginalised historical characters or events.

\section{Robert Wedderburn's Vagrancy and Scotland's Amnesia}

In discussing Scotland's relation to its multicultural and imperial histories, a vagrant narrative is again illuminating. The ex-Royal Navy sailor, journeyman tailor, Spencean activist and proto-Anarchist, Jamaican freeborn, firebrand Robert Wedderburn (1762-1835?) spent the majority of his life as a landlubber and eventually revolutionary in London. However, his Scottish lineage was crucial to his identity and led to a series of letters in the journal Bell's Life in London in 1824 in which he sought to establish his claims as the son of the Jamaican planter James Wedderburn and a black freewoman against his half-brother Andrew Colville's denial of any family relationship. In these letters he describes his rejection

Formatted: Font: Bold

Formatted: Font: Bold

Commented [ZAA3]: If there is uncertainty concerning the year of death please note that briefly in the text or in a footnote. 
by his father when he had travelled to Inveresk Lodge near Musselburgh on the outskirts of Edinburgh in 1785. It was poverty that drove him to make the four hundred 400 mile journey to claim some kind of inheritance. Arriving by boat, he walked up from the port to the big house on the other side of the town and described what happened thus:

It was seven years after my arrival in England that I visited my father, who had the inhumanity to threaten to send me to gaol if I troubled him. I never saw my worthy father in Britain but this time and then he did not abuse my dear mother [...] nor did he deny me to be his son, but called me a lazy fellow, and said he would do nothing for me. From his cook I had one draught of small beer, and his footman gave me a cracked sixpenceand these are all the obligations I am under to my worthy father [...]. It is false when my brother says I was taken before the Sherriff of the County-I applied to the Council of the City of Edinburgh for assistance, and they gave me 16d. and a travelling pass; and for my passage up to London I was indebted the Captain of a Berwick smack. (McCalman 1991, 59-60)

The description of his visit shows him treated as a vagrant by his father. However, Wedderburn keeps his dignity by managing to arrange his penniless passage home relying on the law and the kindness of strangers, absent from his own family home. What Wedderburn does by his visit is to bring to the home built with riches from Jamaica the visible black presence that highlights where the profits have come from. He emphasises here the meanness of his reception, not as a prodigal son but as a nuisance to be got rid of with meagre charity. This encounter is especially important in Scotland where its contribution to the horrors of slavery and imperialism have traditionally been downgraded and where the black presence has been all too readily elided. As Michael Morris argues:

The recuperation of often-overlooked non-white historical figures has immediate resonances in relation to Bernard Schoene’s “"post-devolution”’' agenda of opening up Scottish national narratives to wider issues of "“class, sexuality and gender [...] cosmopolitanism and postcoloniality, as well as questions of ethnicity, race and postnational multiculturalism.'”’ (Morris 2015, 169)

The working-class activist Wedderburn's sojourn to the land of his father allows him to intervene in a Scottish domestic space of calm, imperial well-being and expose its being built

Commented [R4]: Original emphasis? Yes!!

Commented [R5]: Original emphasis? Yes!! 
on the transnational horrors of plantation slavery. Scotland's complex and compromised past is laid bear by the recuperation of Wedderburn's story. Wedderburn was later to publish this account in his 1824 pamphlet The Horrors of Slavery but it was not until a 2007 reconstruction of the walk as part of Scotland's commemorations of the Abolition Bicentenary that Robert Wedderburn's Scottish lineage was truly celebrated in the local space of the white Wedderburn family. This powerful memorial walk led by Robert's direct descendant Bil Wedderburn attracted nearly three hundred 300 participants partly because of its sponsorship by Scottish Churches as part of their bicentenary commemorations.

Unfortunately, this marvellous reinsertion of Robert Wedderburn into the narrative of the town to join his father, whose presence is readily remembered in road names and the local poor house named after him because of his local (and ironic) philanthropy and now converted into luxury flats, did not survive at Inveresk Lodge Gardens, where on a visit in 2014 there was no longer any record of the event. The National Trust for Scotland, who owns the gardens, far from seeing the visit as a seminal event to celebrate a multicultural Scotland, are prepared to let it be forgotten by not including any mention of the link to this iconic black figure or the walk that celebrated him in their displays about the location. Local activists are refusing to let Robert Wedderburn be elided, however, and are using tactics of guerrilla memorialisation to make sure his legacy is not forgotten. The blogger Ewan Davidson uses this elision of Wedderburn to highlight Scotland's inability still to come fully to terms with its slave past preferring to highlight its status as victim of historical crimes rather than perpetrator through its slaveholding citizens:

My own view is that Scotland can never truly exist unless it acknowledges a past it created, rather than a series of things that were done to it, and that one of those things was to exploit people, some Scots, most not [...]. So I have a campaign which I will follow like RW when and how I am able. I want to spread awareness of RW and his story [...]. What I really want is to make sure that a link to RW remains stubbornly at Inveresk Lodge. I have made some small impacts by regularly updating their visitor's book like the Spenceans who operated in the underground for a long time, the message will sometimes need to be chalked on the walls. (Davidson 2015, n. pag.)

Such guerrilla activity seeks to make Scotland's history broader and include its black voices as essential to a full understanding of the history warts and all. Wedderburn only spent a few days 
in Scotland, but his exilic presence is still making its graffiteed marks felt working through radical forces as a ghostly means to make a full accommodation to the past.

\section{Rural North Britain and Vagrant Black Presences Then and Now}

Vagrant and underground activity is a marker of many African Atlantic presences whose restitution as central to the story of the Black Atlantic means that historians and cultural commentators will narrate a fuller, more nuanced and less majoritarian account of Black British history and culture. The St. Kitt's-born, Leeds-raised writer Caryl Phillips conjures some of these presences and their haunting of the present in his The Lost Child (2015), partly a prequel to Emily Brontë's Wuthering Heights, which interrogates this history, riffing on the novel's description of Heathcliff as 'a regular black,' brought from the slave port of Liverpool to the Yorkshire Moors, to speculate about a black presence shadowing and helping to create the gothic masterpiece. Rumours of African slaves (kept on as labourers after the end of slavery) working at farms in Dent, Yorkshire, close to where the Brontë sisters went away to school, are shown as key in the fevered imagination of Emily, whose death in Phillips's novel is preceded by her mixing fact and fantasy to imbricate her own family as source for Heathcliff's arrival at Wuthering Heights:

Dear Charlotte, do you remember when Papa deserted us for Liverpool and returned with the boy? The strange boy with blazing eyes who had lost his place in the world. Papa wrapped him in his cloak and brought him to us, do you remember. (Phillips 2015, 110)

Phillips weaves this narrative of a famous fictional lost child with that of two mixed-raced boys growing up in Leeds in the 1960s and 1970s where the gritty late-industrial realities are mixed with an insular racism that scars them and affords them no easy escape. What is remarkable for Phillips is how little has changed in terms of the demonising of the other since the time when the British Empire painted the maps red; this is exacerbated by the lack of a black community in these mean streets. In an autobiographical vignette, he describes this petty racism:

I am seven years old and everything is happening too fast. I kiss a girl outside school. On the cheek. A light kiss, but nevertheless the kind of kiss that seven-year-olds should 
not know about. A cluster of parents stand by and look on with horror [...]. My sooty touch on their tiny Desdemona in the working-class streets of Leeds. (Phillips 2001, 3)

Phillips invokes Shakespeare's Othello to illustrate the deep historical resonances of interracial encounter and the way it is imbricated in Britain's cultural tradition from the Bard to the Brontës even if at times it is hidden in plain sight. As part of his tour for the book in 2015, Phillips read from his new novel at the Brontë Parsonage Museum at Haworth. In the Q \& A session which I chaired, he was at pains to stress his affiliation to Yorkshire despite its early disavowal of him, articulating his regional roots as being as important to him as the cosmopolitan routes that have led him to a life in America. He described his debt to a range of northern realist writers from Barry Hines and Shelagh Delaney through to Alan Bennett whose clipped Yorkshire brogue is a recognisable source whenever Phillips' fiction is set in 'God's Own Country.' He visibly warmed to the local audience and his mid-Atlantic vowels had disappeared by the end of the evening, illustrating the importance of fleshing out multiple identities—class, regional, national and trans-national—in order to fully understand what Paul Gilroy has termed Black Atlantic modernity. Gilroy had contended that "national units are not the most appropriate basis for studying this history for the African diaspora's consciousness of itself has been defined in and against constricting national boundaries (Gilroy 1993, 158). His call for the importance of the transnational in articulating black identities was a crucial intervention in urging a more cosmopolitan black identity, but this should be accompanied by attention to the regional homespace wherein this black voice is often articulated with a local accent. Such multiple identities are often obscured and ignored in metropolitan accounts, and the black presence beyond London is all too often marginalised and ignored in Black British identity. Novelists like Phillips bring it back centre-stage.

A new generation of Bblack artists are getting to grips with these multiple identities and trying to make sense of being black in northern Britain. They are following on from artists like Ingrid Pollard who made forays into the rural North as a tourist in her photographic series Pastoral Interlude (1987). Visiting Wordsworth country, Pollard finds herself alienated from the land experiencing an "unbelonging” that she captures in a series of portraits of black men, women and children posed as tourists. In one image a black walker is taking a rest, camera on her knees. Pollard's text muses:

[I]t's as if the Black experience is only lived within an urban environment. I thought I liked the Lake District where I wondered lonely as a Black face in a sea of white. A 
visit to the countryside is always accompanied by a feeling of unease, dread. (Pollard 2005, 20-21)

Pollard's sassy, ironic take on $\underline{b} B$ lack exclusion from rural narratives and her guerrilla attempt to reinsert Bblack presence at the heart of heritage Britain makes space for more radical work that talks about the space as home space in the here and now. I would like to conclude this study by discussing the work of a young artist who appears to be following in this vagrant/underground tradition of making the landscape a homespace despite marginalisation. Jade Montserrat, born and brought up near Scarborough, where she talks about being 'a lonely black presence,' has consciously used the gothic sensibilities of the Brontës to create works that interrogate her blackness. In her video performance piece Clay she uses her naked black body to dig and mould the Yorkshire earth into what seems to be a burial pit or grave; she describes the scene as "bleak, remote, unforgiving, unhearing, without union or unity with other bodies.” Her black body has no companion, it has "lost its place in the world,” and there seem to be no other bodies like it in the historical landscape (Montserrat 2015, n. pag.). In her accompanying text piece to her video works she describes how:

Heathcliff, representative of the dispossessed, and I are aliens dropped into this ancient landscape. Appearances suggest we were not meant to be here. Alienation is magnified by a landscape scarred by borders, a testimony to territorial ownership. (Montserrat 2015, n. pag.)

Vagrant presences in a landscape owned by aristocratic masters (she filmed her piece on land she has lived on most of her life but which is a private shooting estate), Heathcliff and her are similarly dispossessed and alienated. And yet Montserrat's piece has a haunting beauty and a redemptory coda: as she digs the pit with her bare hands, mud caking her body, she moulds mud bricks and builds them into a wall shape, mimicking the Yorkshire art of dry stone walling, constructing a shelter in the local manner as she simultaneously digs her grave. Her discovery of homespace in the alien environment can be compared to the trope built on the historical escape route for slaves, the Underground Railroad, which Katherine McKittrick suggests as “ black geography that reframes spatial knowledge" creating a "radically different sense of place” (qtd. in Gerund 2013, 102). In Yorkshire, Montserrat combines this radicalism with the home comfort of local tradition creating a Northern, vagrant, black solution to the alienation caused by the elision of black presence from the Yorkshire history and landscape. Her grave 
space, the burial site for black hopes and dreams might yet be redemptory: the border she constructs might just be a sheltering home. She quotes Homi Bhabha: "the state of emergency is always a state of emergence” (Bhabha 1994, 41), and she seems to be saying through her digging toil that for African Atlantic people who have found themselves in northern England as 'Lost Children,' making lives out of these dangers, there is hope in survival, in making their presence felt. Dionne Brand describes the ambivalences Montserrat navigates thus:

To live in the Black Diaspora is I think to live as a fiction-a creation of empires, and also self-creation. It is to be a being living inside and outside of herself. It is to apprehend the sign one makes yet be unable to escape it except in radiant moments of ordinariness made like art. (Brand 2001, 18-19)

Montserrat's radiant moment is in the beauty of the images she creates as she constructs her shelter/grave. She makes of the ordinary, usually forgotten, vagrant presence a marvellous translucence through the work of her labouring black body alone: she makes it into art. The Scottish-Ghanaian black artist/poet Maud Sulter (1960-2008) articulates the power of such artistic black survival in a white-dominated world in the final stanza of her poem 'A Brief Introduction:':

\section{HISTORY IS WRITTEN BY THE VICTORS \\ OR SO THEY SAY, LET US SUFFICE \\ TO SAY THAT IT IS THE SURVIVOR \\ OF THIS TALE THAT HANGS OUT \\ HER STORY TO DRY ON THE \\ WASHING LINE OF REMEMORY (Sulter 2015, 7a)}

The articulate stories I have outlined in this article are those of survivors whose ${ }_{2}$ often vagabond presences expand the range of the Black Atlantic from the macro to the micro, from the transnational to the local and hence allow new stories to dry out on that re-memory washing line. Michael Rothberg's compelling suggestion that by "aggressively foregrounding the 'haunting past'” the artists and writers who live and/or interpret such lives "do not produce divisiveness, but rather seek to uncover already existing, unresolved divisions. Their acts of uncovering hidden histories, traumas and social divisions constitute the ethical dimensions of multidirectional memory” (Rothberg 2009, 270), which compels us as critics to look beyond 
essentialised and narrow notions of origins or racial politics to find in the vagabond and vagrant, the rural and the marginalised, the interconnected narratives that tell new stories of the Black Atlantic often far from the ocean waves which were its spawning grounds.

\section{Works Cited}

“BBC’s ‘Black History of Britain’ to feature Cotton Famine Road at Lane Head” (2016). Rochdale

Online. August 2. < <ttps://www.rochdaleonline.co.uk/news-features/2/newsheadlines/104384/bbcs-black-history-of-britain-to-feature-cotton-famine-road-at-lanehead> (December 6, 2016).

Bhabha, Homi K. (1994). The Location of Culture. London: Routledge.

Brand, Dionne (2001). A Map to the Door of No Return: Notes to Belonging. Toronto: Doubleday.

Davidson, Ewan (2015). “Traces of Robert Wedderburn.” Riverofthings. May 26, 2015. <https://riverofthings.wordpress.com/2015/05/26/traces-of-robert-wedderburn/> (October 21, 2016).

"Flour Barrel.” Revealing Histories: Remembering Slavery. n.d. $<$ http://revealinghistories.org.uk/the-american-civil-war-and-the-lancashire-cottonfamine/objects/flour-barrel.html> (October 21, 2016).

Gerund, Katharina (2013). Transatlantic Cultural Exchange: African American Women's Art and Activism in West Germany. Bielefield: Transcript.

Gilroy, Paul (1993). The Black Atlantic: Modernity and Double-Consciousness. London: Verso.

Gilroy, Paul, (2004). After Empire: Melancholia or Convivial Culture. Abingdon: Routledge. Johnson, James (1914). The Life of the Late James Johnson, Coloured Evangelist: An Escaped Slave from the Southern States of America, 40 Years Resident in Oldham, England. Oldham: Galley.

“Lennon’s Poster.” Digital Image. Pinteresting. October 09, 2012. <http://archive.printeresting.org/2012/10/09/lennons-poster/> (October 21, 2016).

McCalman, Iain, ed (1991). Horrors of Slavery and Other Writings by Robert Wedderburn. Princeton, NJ: Wiener.

Morris, Michael (2015). Scotland and the Caribbean c.1740-1833: Atlantic Archipalagos. London: Routledge. 
Montserrat, Jade (2016). "Burial, the Brontes and Lost Children, a Text and Film Performance at IBAR UCLan Symposium Lost Children: The Black Atlantic and Northern Britain, Friday 1st May 2015” Jademontserratdotcom. October 28 $<$ https://jademontserrat.com/2016/10/28/burial-the-brontes-and-lost-children-a-text-andfilm-performance-at-ibar-uclan-symposium-lost-children-the-black-atlantic-and-northernbritain-friday-1st-may-2015/> (December 6, 2016).

Phillips, Caryl (2001). A New World Order. London: Secker.

Phillips, Caryl (2015). The Lost Child. London: Oneworld.

Pollard, Ingrid (2005). Postcards Home. London: Autograph.

Rothberg, Michael (2009). Multidirectional Memory: Remembering the Holocaust in the Age of Decolonization. Stanford, CA: Stanford University Press.

Sulter, Maud (2015). Passion. London: Altitude.

Turner, John M (2003). “Pablo Fanque, Black Circus Proprietor.” Gretchen Holbrook Gerzina, ed. Black Victorians, Black Victoriana. New Brunswick, NJ: Rutgers University Press, 20-38. 